\title{
Penyusunan Basis Data Modul Penyerap Impak Internal Inversion
}

\author{
Rachman Setiawan ${ }^{1}$ dan Delima Yanti Sari ${ }^{2}$ \\ ${ }^{1}$ Program Studi Teknik Mesin Institut Teknologi Bandung, Bandung \\ 2Jurusan Teknik Mesin Universitas Negeri Padang, Padang \\ Email: delimayanti@yahoo.com
}

\begin{abstract}
ABSTRAK
Penggunaan modul penyerap energi impak merupakan suatu alternatif dari aplikasi teknologi crashworthiness. Penelitian eksperimental yang komprehensif terhadap karakteristik modul tersebut memerlukan biaya yang tinggi, sehingga simulasi komputer yang menggunakan metode elemen hingga menjadi pilihan alternatif. Penggunaan metode elemen hingga dalam proses perancangan melalui optimasi iteratif, biasanya membutuhkan waktu komputasi yang cukup lama. Oleh karena itu, proses perancangan berbasis data (knowledge based design) perlu disusun sehingga proses optimasi rancangan dapat dilakukan secara efisien dan tidak menimbulkan permasalahan numerik. Dalam penelitian ini, perancangan berbasis data dilakukan pada modul penyerap impak mekanisme internal inversion dengan tujuan untuk mengetahui pengaruh dimensi modul terhadap karakteristik crashworthiness-nya, menyusun basis data karakteristik modul yang akurat dan komprehensif, serta menyusun dan menerapkan metodologi perancangan optimum modul berdasarkan basis data. Dalam makalah ini akan dipaparkan proses penyusunan basis data modul penyerap impak internal inversion.
\end{abstract}

Kata kunci: Crashworthiness, internal inversion, perancangan berbasis data.

\begin{abstract}
The use of impact energy absorbing modules is an alternative approach to the application of crashworthiness technology. Comprehensive research of the characteristic of modules through experimental method is very expensive. Alternatively, computer simulation using finite element method can be used. Design process using iterative optimization with finite element method for function evaluation, normally requires high computational cost. Therefore, knowledge based design methodology is proposed in order to perform an efficient optimization process as well as to avoid numerical problems. In this research, knowledge based design is carried out on impact energy absorbing modules, internal inversion. The objectives of this research are to find out the effect of module dimension to its crashworthiness characteristic, to generate an accurate and comprehensive database of internal inversion characteristic and to propose and apply knowledge based design methodology of internal inversion. In this paper, generating process of internal inversion characteristics database is reported.
\end{abstract}

Keywords: Crashworthiness, internal inversion, knowledge based design.

\section{PENDAHULUAN}

Crashworthiness didefinisikan sebagai kemampuan suatu struktur dalam melindungi keselamatan kargo atau penumpang ketika terjadi tabrakan (impact). Manajemen penyerapan energi impak pada kendaraan yang mengalami tabrakan dapat dilakukan secara terintegrasi pada struktur kendaraan itu sendiri, atau dengan cara menambahkan suatu sub-struktur yang disebut dengan modul penyerap impak. Penggunaan modul ini dinilai sangat menguntungkan karena parameter respon impak dapat diprediksi dengan baik, modul dapat diproduksi maupun di-reproduksi dengan mudah dan relatif murah. Selama ini perancangan modul penyerap impak masih bersifat coba-coba, karena kurangnya informasi mengenai karakteristik modul. Untuk mencari rancangan yang feasible, dibutuhkan pemahaman karakteristik yang lebih rinci dan komprehensif sehingga dapat diketahui pengaruh parameter perancangan dan korelasinya terhadap parameter crashworthiness. Untuk mengetahui karakteristik modul secara detail perlu dilakukan banyak eksperimen. Karena eksperimen secara fisik sangat mahal dan sulit dilakukan, maka eksperimen komputer menggunakan metode elemen hingga menjadi pilihan untuk analisis karakteristik modul. Namun, simulasi/analisis elemen hingga dalam proses optimasi iteratif biasanya membutuhkan waktu komputasi yang cukup lama dan sering 
terkendala dengan permasalahan numerik seperti ill condition, ketidakstabilan, divergensi dan lainlain, sehingga proses optimasi atau perancangan menjadi terhambat. Oleh karena itu, dalam penelitian ini; suatu metodologi perancangan berdasarkan basis data disusun untuk meminimalisasi waktu dan permasalahan numerik dalam perancangan modul penyerap impak yang optimal.

Perancangan berbasis data adalah metode perancangan yang menggunakan basis data yang relevan untuk memperoleh solusi optimal. Basis data tersebut berupa pasangan parameter masukan dan keluaran. Dalam penelitian ini parameter masukan merupakan parameter perancangan tanpa dimensi dan parameter keluaran berupa parameter crashworthiness yang diperoleh dari analisis elemen hingga terhadap parameter masukan. Kemudian, berdasarkan kedua parameter tersebut dikembangkan suatu sampel untuk memperoleh model analitik sehingga dihasilkan korelasi numerik antara parameter masukan dan keluaran. Proses perancangan ini dikenal dengan sebutan metamodeling. Dengan diketahuinya korelasi tersebut, metamodeling dapat digunakan untuk memprediksi nilai parameter keluaran dengan cara yang lebih mudah dibandingkan dengan analisis elemen hingga. Selanjutnya, untuk memperoleh rancangan yang optimal fungsi eksplisit yang didapat dari proses metamodeling digunakan dalam proses optimasi rancangan.

Ide dasar metamodeling adalah membangun model prediksi dari suatu model analisis kompleks, yang merupakan fungsi dari variabel perancangan, serta memberi prediksi hubungan antara parameter performance sistem dan parameter perancangan berdasarkan harga fungsi pada beberapa titik sampel. Titik sampel tersebut digenerasi berdasarkan metode perancangan eksperimen (experimental design atau design of experiment) seperti factorial design, latin hypercube dan lain-lain. Sementara itu, nilai parameter performance sistem diperoleh melalui simulasi atau analisis numerik yang dilakukan pada tiap titik sampel. Untuk menjamin keakuratan model yang merupakan pengganti fungsi asli perlu dilakukan validasi terhadap model prediksi yang diperoleh. Validasi dapat dilakukan dengan berbagai metode statistik. Setelah divalidasi, model tersebut nantinya dapat digunakan untuk menfasilitasi proses optimasi.

Proses optimasi berdasarkan metamodel oleh Wang et al. [1] disebut juga metamodel based-design optimization (MBDO) yang secara umum terdiri atas proses pengambilan sampel, pembentukan metamodel, validasi model dan optimasi bersadarkan metamodel. Wang et. al [2] juga memberikan metodologi serupa, namun dengan pendekatan strategi adaptive $M B D O$ dimana terdapat iterasi proses perancangan eksperimen dan model fitting.

Dalam penelitian ini perancangan berbasis data dilakukan terhadap modul penyerap impak meka- nisme internal inversion. Gambaran umum mengenai karakteristik modul penyerap impak mekanisme internal inversion dan axial splitting telah diberikan $\mathrm{R}$ Setiawan et. al [3].

\section{METODE PENELITIAN}

Alur metode penelitian yang dilakukan, secara umum dapat dilihat pada Gambar 1.

Penelitian diawali dengan pembuatan model elemen hingga modul internal inversion yang sesuai dengan eksperimen yang telah dipublikasikan oleh Reid dan Harrigan[4]. Untuk validasi, akurasi model diuji dengan memperbandingkan hasil simulasi numerik dengan hasil eksperimen. Hasil validasi yang dilakukan oleh R Setiawan dan Delima Yanti Sari [5], menunjukkan bahwa hasil simulasi numerik tidak jauh berbeda dengan hasil eksperimen, sehingga model elemen hingga tersebut cukup akurat untuk digunakan dalam pembuatan basis data modul internal inversion. Selanjutnya dalam makalah ini akan disajikan proses penyusunan basis data modul penyerap impak internal inversion. Proses penyusunan basis data terdiri atas beberapa tahap penting, yaitu:

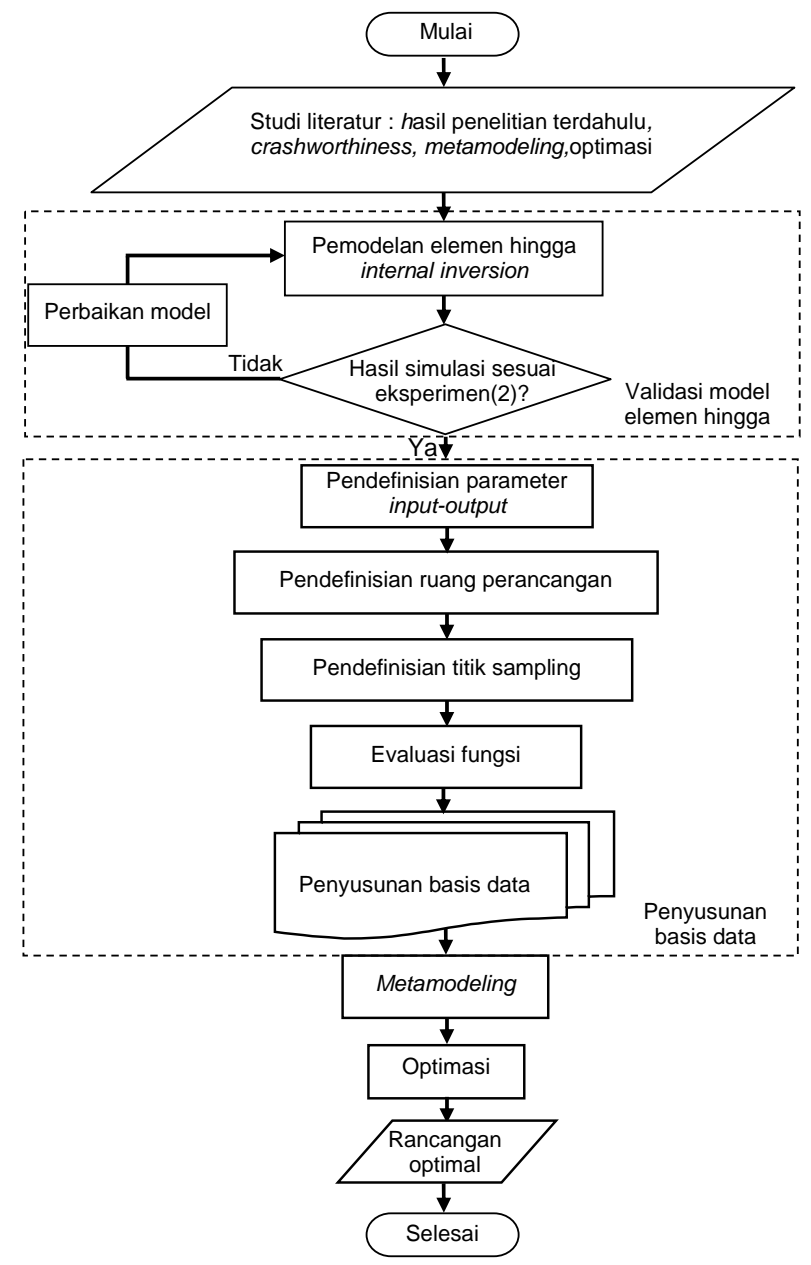

Gambar 1. Alur Penelitian Metode Perancangan Berbasis Data 
1. Pendefinisian parameter masukan dan keluaran tanpa dimensi

2. Pendefinisian ruang perancangan parameter masukan.

3. Pengambilan sampel parameter masukan.

4. Analisis elemen hingga atas parameter masukan.

5. Penyusunan pasangan parameter-parameter masukan dan keluaran secara teratur dalam file basis data.

\section{Pendefinisian Parameter}

Parameter masukan dipilih berdasarkan pada parameter perancangan tanpa dimensi. Untuk modul internal inversion, parameter perancangan ini meliputi diameter luar pipa, $D_{o}$, tebal pipa, $t$, radius kelengkungan cetakan, $R_{d}$, dan panjang pipa, $h$, seperti pada Gambar 2.

Untuk generalisasi kasus, ditentukan parameter masukan tanpa dimensi, yaitu $D_{o} / t$ dan $D_{o} / R_{d}$. Parameter pertama menggambarkan faktor bentuk dari modul pipa, sementara parameter kedua menggambarkan pengaruh radius kelengkungan cetakan.

Parameter keluaran harus mewakili karakteristik crashworthiness struktur penyerap impak, yang antara lain harus melibatkan gaya keadaan tunak dan energi yang diserap. Informasi mengenai gaya keadaan tunak diperlukan dalam pemilihan modul penyerap impak untuk suatu aplikasi. Gaya yang terlalu besar dapat menyebabkan tingginya perlambatan yang dirasakan oleh penumpang/ kargo. Biasanya, nilai gaya semacam ini merupakan suatu batas atas dalam optimasi perancangan modul penyerap impak. Selanjutnya, penyerapan energi yang tinggi merupakan sasaran optimasi rancangan modul. Namun, hal ini harus mempertimbangkan dimensi maupun massa modul. Oleh karena itu, dipilih $E_{o} / V$ dan $F_{S S} /\left(D_{o} t\right)$ sebagai parameter keluaran.

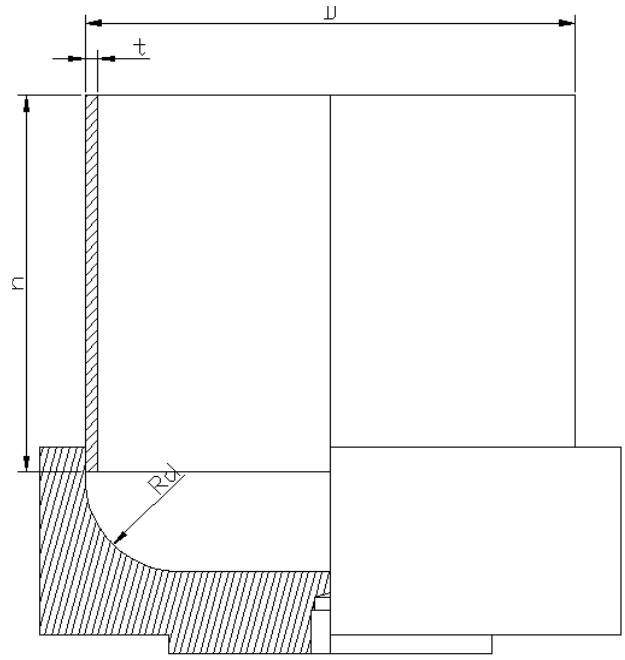

Gambar 2. Parameter Perancangan Internal Inversion
$E_{o} / V$ adalah parameter keluaran energi yang diserap per volume modul atau disebut juga efisiensi volumetrik [8]. $F_{S S} /\left(D_{o} t\right)$ menggambarkan gaya keadaan tunak relatif dibandingkan dengan penampang pipa .

\section{Pendefinisian Ruang Perancangan}

Dalam perancangan modul penyerap impak, terdapat beberapa kriteria yang harus dipenuhi. Selain harus memenuhi kriteria keselamatan, modul penyerap impak diharapkan bisa menyerap energi secara maksimal. Untuk itu perlu dilakukan kontrol dalam perancangan modul penyerap impak melalui pengontrolan karakteristik gaya dan deformasi modul.

Suatu modul penyerap impak dikatakan ideal apabila memiliki karakteristik seperti pada Gambar 3. Energi yang mampu diserap oleh modul, dapat dilihat pada luas daerah di bawah kurva. Gaya maksimum, $F_{\text {max }}$, dibatasi oleh kriteria keselamatan. Untuk memaksimumkan jumlah energi impak yang dapat diserap, diperlukan respon yang datar.

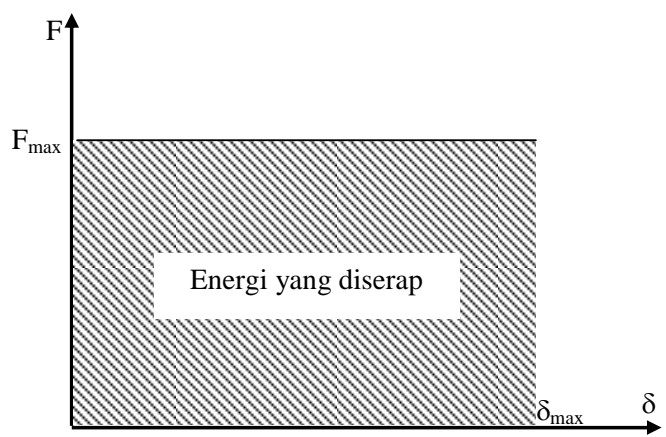

Gambar 3. Karakteristik Penyerapan Impak Ideal Modul/Struktur [3]

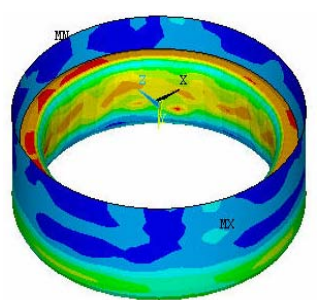

(a) Deformasi Pipa

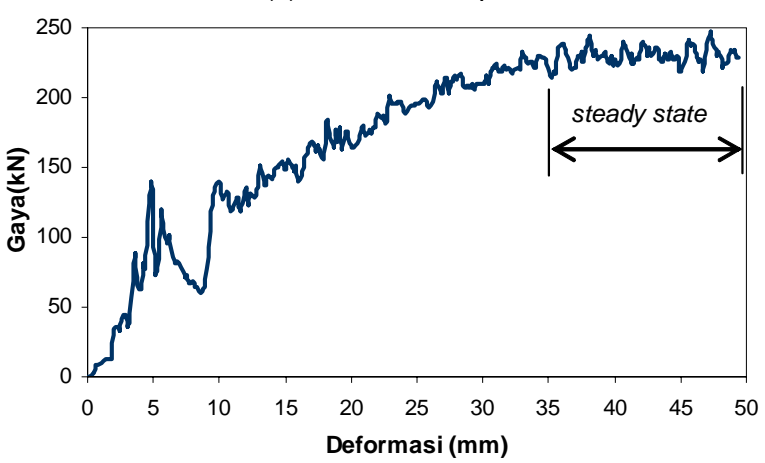

(b) Hubungan antara Gaya dan Deformasi

Gambar 4. Mekanisme Internal Inversion 
Untuk modul penyerap impak internal inversion, karakteristik yang diinginkan adalah seperti terlihat pada Gambar 4. Dengan kondisi gaya yang keadaan tunak, tidak terjadi peningkatan gaya yang diteruskan ke penumpang, dan energi yang diserap lebih maksimal.

\section{Sampling Parameter Masukan}

Setelah diketahui batas-batas ruang perancangan modul internal inversion, langkah selanjutnya dalam penyusunan basis data adalah pendefinisian titik sampel (training data) dalam ruang perancangan, yang dilakukan dengan teknik perancangan eksperimen (Design of Experiment). Training data adalah sekumpulan terbatas dari data yang dimaksudkan sebagai parameter masukan. Parameter ini berupa kombinasi parameter perancangan modul, yaitu $D_{o} / t$ dan $D_{o} / R_{d}$. Karena karakteristik modul belum diketahui, maka dibutuhkan titik sampel yang tersebar merata dalam ruang perancangan. Hal ini bertujuan agar informasi karakteristik modul dapat dikumpulkan secara maksimal. Dalam perencanaan terdapat beberapa strategi untuk mendefinisikan distribusi titik sampel. Strategi tersebut tergantung pada pemilihan model prediksi dan kriteria statistik yang dipakai. Dalam penelitian ini, metode Latin Hypercube Sampling (LHS) [7] digunakan untuk menghasilkan titik sampel secara acak. Metode ini dipilih, karena mampu menjamin distribusi titik sampel yang seragam untuk setiap variabel perancangan[7].

\section{Analisis Elemen Hingga}

Analisis elemen hingga dilakukan dengan bantuan Ansys/Ls-Dyna versi 9. Sementara itu, pembuatan model elemen hingga dilakukan secara parametrik sesuai dengan model yang telah divalidasi [5]. Dalam pembuatan model, data parameter masukan yang diperoleh dari perancangan eksperimen diubah menjadi dimensi nyata yang berupa ketebalan dan radius kelengkungan cetakan dengan diameter tertentu. Kemudian, model elemen hingga yang didapat dianalisis secara massal dengan looping untuk tiap parameter masukan, sehingga diperoleh satu file hasil untuk tiap kombinasi ketebalan pipa dan radius cetakan. Untuk tiap diameter yang sama akan dihasilkan jumlah file sesuai dengan jumlah titik sampel. File tersebut berupa dokument teks yang memuat data parameter crashworthiness seperti deformasi, gaya kontak dan energi yang diserap terhadap waktu. Data deformasi diambil dari perpindahan/stroke yang dialami oleh penumbuk, sedangkan gaya kontak diambil dari resultan gaya interface antara pipa dan pembatas bawah. Selain itu, data energi yang diserap pipa, diambil langsung dari option keluaran energi yang sudah tersedia.

\section{Penyusunan Basis Data}

Setelah diperoleh, hasil analisis diolah dan dipilih untuk mendapatkan parameter crashworthiness yang dibutuhkan yaitu gaya keadaan tunak dan energi yang diserap. Parameter ini kemudian diubah menjadi parameter keluaran $F_{S S} /\left(D_{o} t\right)$ dan $E_{o} / V$ dan disimpan dalam suatu file yang terdiri dari pasangan parameter masukan dan keluaran tersebut.

\section{HASIL DAN PEMBAHASAN}

\section{Ruang Perancangan}

Dari hasil observasi atas simulasi modul internal inversion yang dilakukan dengan variasi diameter pipa, ketebalan pipa dan radius kelengkungan cetakan, terdapat beberapa mekanisme dan karakteristik penting, yaitu:

1. Dengan meningkatnya ketebalan pipa, gaya yang dibutuhkan untuk menginversi pipa semakin besar. Grafik respon gaya terhadap deformasi juga mengalami peningkatan. Pengaruh ketebalan pipa terhadap respon gaya-deformasi untuk beberapa diameter pipa dan radius kelengkungan cetakan dapat dilihat pada Gambar 5.

Jika dibandingkan dengan Gambar 4, karakteristik gaya keadaan tunak yang cukup baik terjadi pada rasio $D_{o} / t \geq 40$. Untuk rasio $D_{o} / t<$ 40 respon gaya terhadap deformasi menunjukkan perilaku nosing, yaitu gaya terus mengalami peningkatan. Hal ini tidak diinginkan dari suatu modul penyerap impak, selain karena besarnya gaya dibatasi oleh kriteria keselamatan, energi penyerapan juga menjadi tidak maksimal untuk panjang stroke yang sama. Dari Gambar 4 dan 5, terlihat bahwa karakteristik respon gaya-deformasi ini terjadi secara konsisten pada diameter yang berbeda. Dengan demikian diungkapkan bahwa karakteristik gaya keadaan tunak yang diinginkan diperoleh pada $D_{o} / t \geq 40$.

2. Radius kelengkungan cetakan sangat berpengaruh terhadap proses inversi. Di satu sisi, radius kelengkungan yang terlalu kecil akan memberikan hambatan dalam proses inversi sehingga menghasilkan respon gaya dengan fluktuasi yang besar. Di sisi lain, radius kelengkungan yang terlalu besar akan menyebabkan terjadinya mekanisme nosing. Kedua hal ini harus dihindari dalam perancangan modul internal inversion. Untuk itu perlu ditentukan radius kelengkungan cetakan yang optimal untuk mendapatkan proses inversi yang ideal. Dari observasi terhadap beberapa simulasi, diperoleh grafik gaya terhadap deformasi seperti terlihat pada Gambar 6 dan 7. 


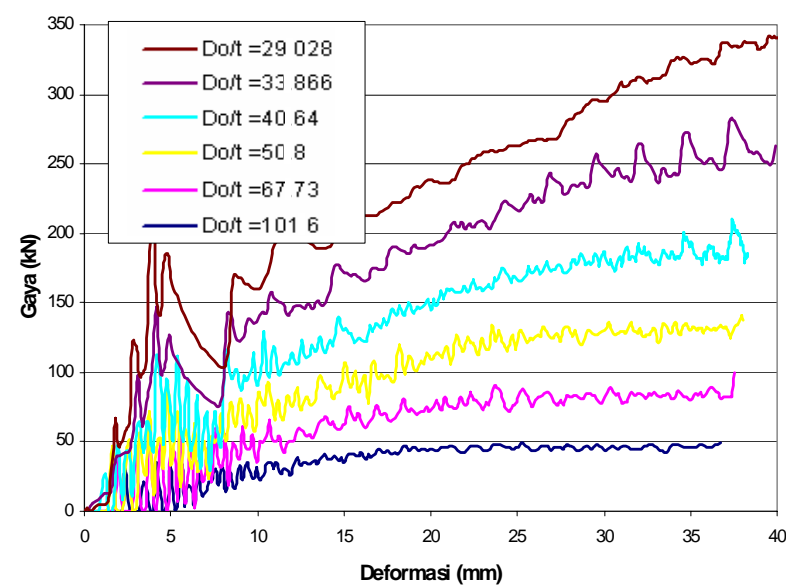

(a) $D_{o}=76,2 \mathrm{~mm}, D_{o} / R_{d}=16,93$

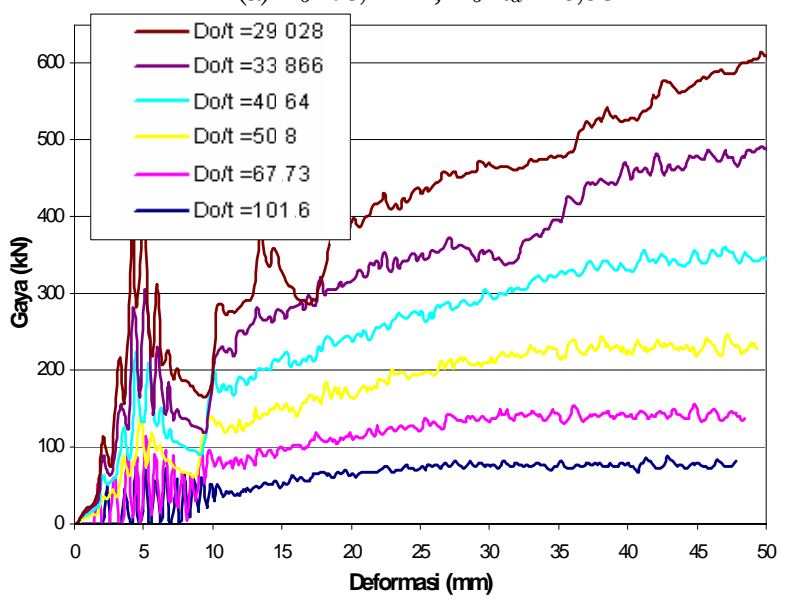

(b) $D_{o}=101,6 \mathrm{~mm}, D_{o} / R_{d}=20,32$

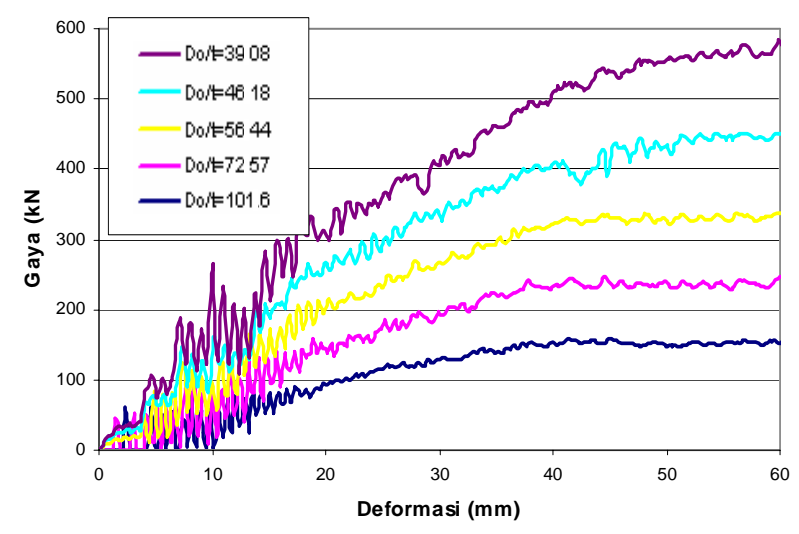

(c) $D_{o}=127 \mathrm{~mm}, D_{o} / R_{d}=12,7$

Gambar 5. Pengaruh Ketebalan Pipa pada Respon Gaya-Deformasi

Gambar 6 memperlihatkan respon gaya-deformasi dengan skala yang sama untuk $D_{o} 76,2 \mathrm{~mm}$ dan ketebalan $0,75 \mathrm{~mm}$ dengan variasi radius kelengkungan cetakan. Gambar 7 memperlihatkan respon gaya-deformasi untuk diameter luar pipa 101,6 $\mathrm{mm}$ dan ketebalan 1,5 mm. Gambar 6(b) dan 7(b) memperlihatkan kondisi keadaan tunak yang diinginkan. Secara umum karakteristik ini terjadi pada $10 \leq D_{o} / R_{d} \leq 25$.
Pada rasio $D_{o} / R_{d}$ yang lebih besar, sebagaimana ditunjukkan pada Gambar 6(a) dan 7(a), respon gaya-deformasi sangat berfluktuasi sebagai akibat dari radius kelengkungan cetakan yang sangat kecil. Namun, pada rasio $D_{o} / R_{d}$ yang lebih kecil, sebagaimana ditunjukkan pada Gambar 6(c) dan 7(c) terjadi perilaku nosing karena radius kelengkungan cetakan terlalu besar. Perilaku ini juga terjadi secara konsisten pada diameter yang berbeda.

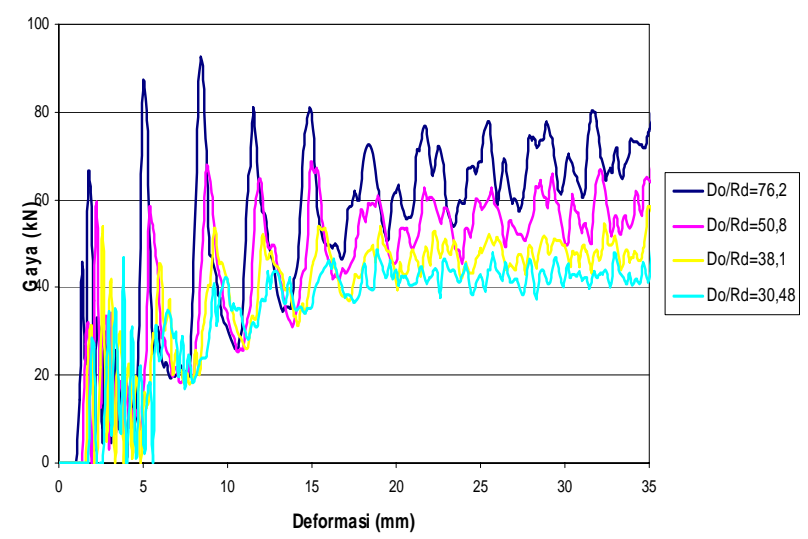

(a) $D_{o} / R_{d}>25,4$

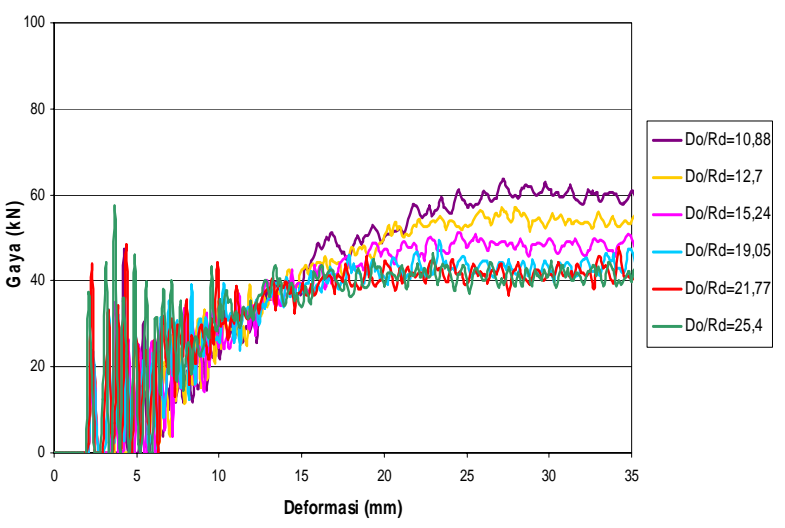

(b) $10,88 \leq D_{o} / R_{d} \leq 25,4$

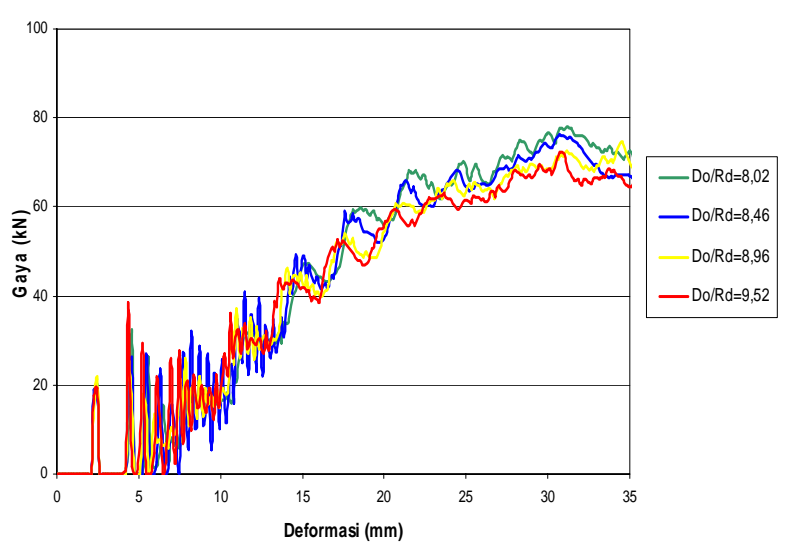

(c) $D_{o} / R_{d}<10$

Gambar 6. Pengaruh $\boldsymbol{R}_{d}$ pada Respon Gaya, untuk $D_{o}=76,2 \mathrm{~mm}, D_{\delta} / t=101,6$ 


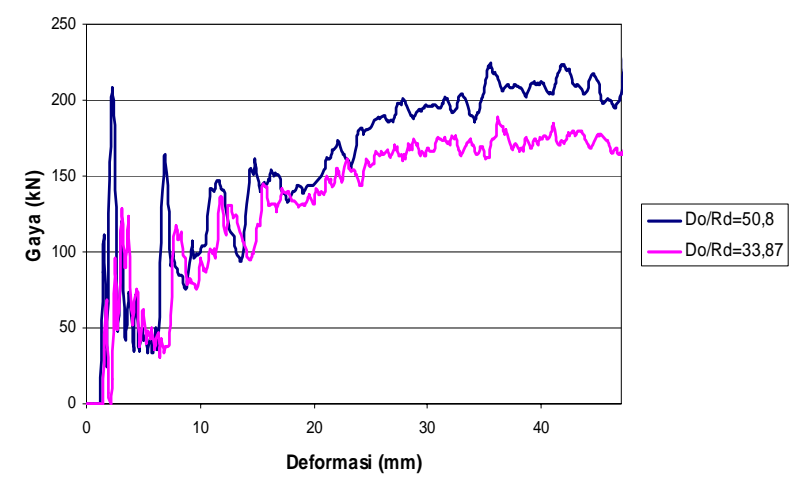

(a) $D_{o} / R_{d}>25,4$

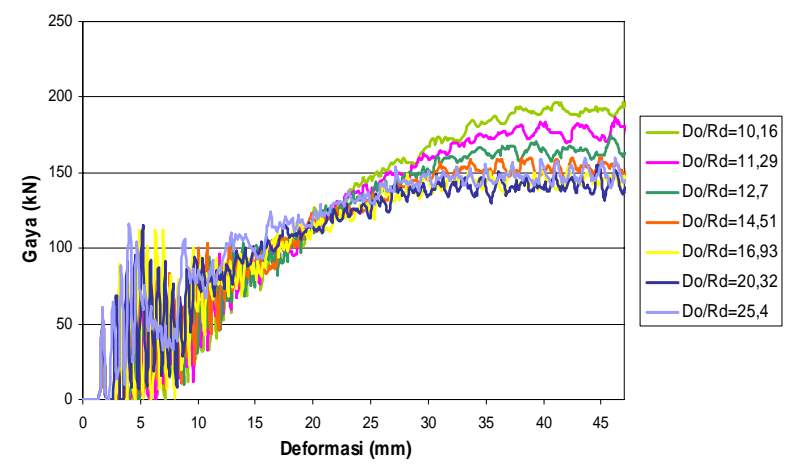

(b) $10,16 \leq D_{o} / R_{d} \leq 25,4$

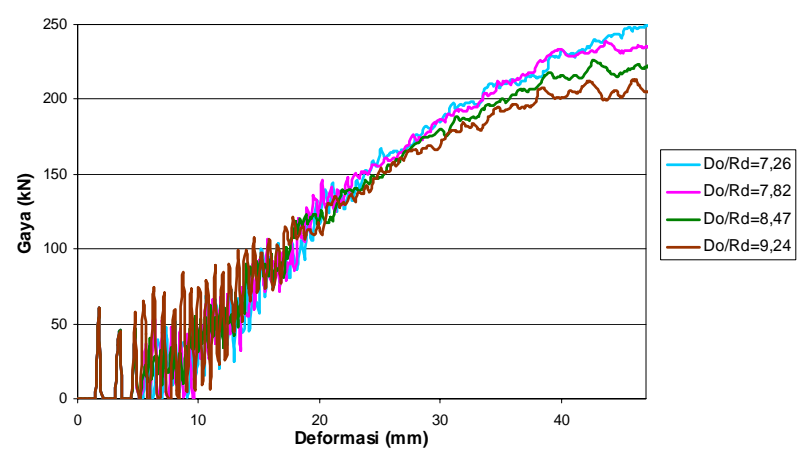

(c) $D_{o} / R_{d}<10$

Gambar 7. Pengaruh $R_{d}$ pada Respon, untuk $D_{o}$ $=101,6 \mathrm{~mm}, D_{o} / t=67,73$

3. Pipa yang terlalu tipis; akan mengalami deformasi dengan mode collapse sebelum pipa terinversi penuh. Fenomena ini dapat dilihat pada Gambar 8. Pada grafik gaya terhadap deformasi, fenomena collapse terlihat dengan adanya penurunan respon gaya, seperti terlihat pada Gambar 8(b). Simulasi deformasi pipa yang mengalami collapse diperlihatkan pada Gambar 8(a).

Gambar 9 memperlihatkan perbandingan fenomena yang terjadi pada diameter pipa, $D_{o} 76,2 \mathrm{~mm}$, radius kelengkungan cetakan, $R_{d} 6 \mathrm{~mm}$ dengan perbedaan ketebalan pipa. Fenomena collapse tidak terjadi pada ketebalan pipa $0,75 \mathrm{~mm}\left(D_{o} / t=101,6\right)$ seperti terlihat pada Gambar 9(a). Namun, sebagaimana ditunjukkan pada Gambar 9(b) pada rasio

$D_{o} / t=152,4$ ini terjadi collapse pada pipa dengan ketebalan $0,5 \mathrm{~mm}$ sebelum pipa tersebut terinversi penuh. Perbandingan grafik respon gaya terhadap deformasi antara kedua rasio tersebut dapat dilihat pada Gambar 9(c). Walaupun penurunan respon gaya-kecil, grafik menunjukkan terjadinya penurunan respon gaya untuk rasio $D_{o} / t 152,4$ pada saat mulai terjadinya collapse.

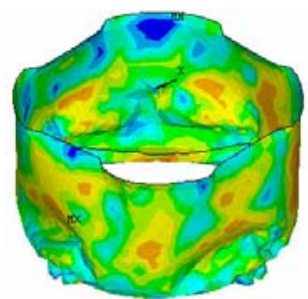

(a) Deformasi Pipa

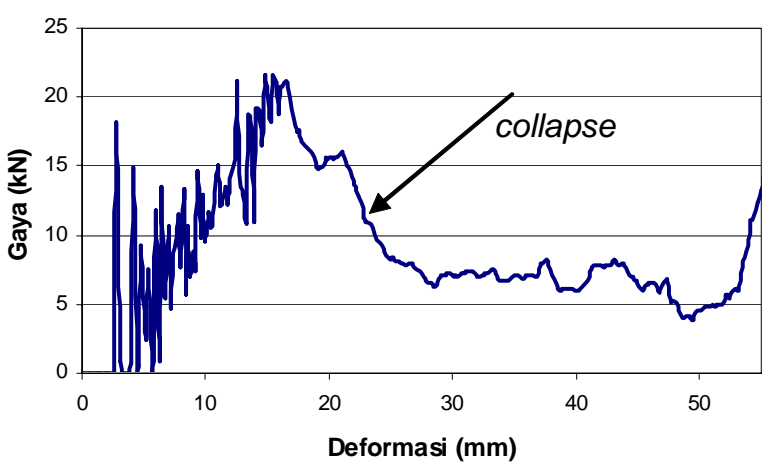

(b) Hubungan Gaya dan Deformasi

Gambar 8. Fenomena Collapse pada $D_{o} 76,2 \mathrm{~mm}, R_{d}$ $4,5 \mathrm{~mm}, D_{d} / t 203,2$

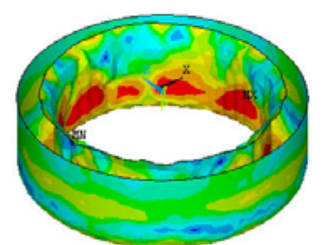

(a) Tidak collapse pada $D_{o} / t 101,6$

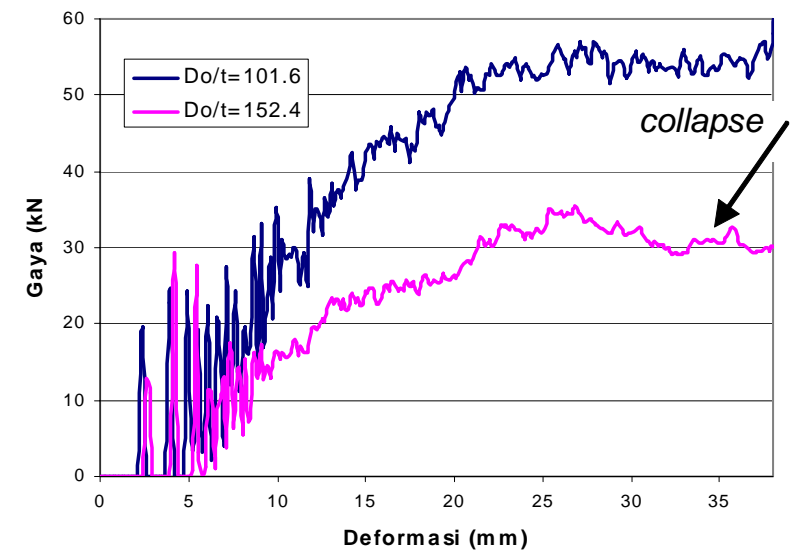

(c) Hubungan Gaya dan Deformasi

Gambar 9. Simulasi Numerik untuk Pipa $D_{o} \mathbf{7 6 , 2}$ $\mathrm{mm}, R_{d} 6 \mathrm{~mm}$ 


\section{Sampling Parameter Masukan}

Hasil perancangan eksperimen adalah data kombinasi $D_{o} / t$ dan $D_{o} / R_{d}$ yang digenerasi dalam batas-batas $40 \leq D_{o} / t \leq 100$ dan $10 \leq D_{o} / R_{d} \leq 25$. Contoh sebaran titik sampel untuk jumlah sampel 200 diperlihatkan pada Gambar 10. Terlihat bahwa dengan metode Latin Hypercube, diperoleh distribusi yang seragam dari data kombinasi parameter masukan dalam ruang perancangan, sehingga dengan jumlah sampel atau kombinasi masukan yang terbatas dapat diperoleh informasi yang dibutuhkan secara efisien.

\section{Analisis Elemen Hingga}

Analisis elemen hingga dilakukan secara massal dengan looping untuk tiap parameter masukan. Gaya keadaan tunak diambil dari gaya rata-rata pada interval stroke tertentu. Pada interval tersebut, sebagaimana ditunjukkan pada Gambar 11, inversi pipa telah memasuki tahap keadaan tunak. Karena karakteristik dan porsi kondisi keadaan tunak tergantung pada ketebalan pipa dan radius kelengkungan cetakan, maka perlu ditentukan interval yang bisa digunakan untuk mengambil data keadaan tunak dari semua kasus ketebalan pipa dan radius kelengkungan cetakan yang berada dalam batas-batas $40 \leq D_{o} / t \leq 100$ dan $10 \leq D_{o} / R_{d} \leq 25$.

Gambar 11 memperlihatkan karakteristik keadaan tunak untuk diameter pipa 76,2 mm. Pipa tebal dengan radius kelengkungan cetakan yang terlalu kecil atau terlalu besar akan menghasilkan kurva gaya keadaan tunak yang pendek. Respon gaya untuk pipa tipis memiliki kurva gaya keadaan tunak yang lebih panjang. Berdasarkan hasil observasi atas beberapa grafik respon gaya dari diameter pipa yang berbeda, agar bisa diperoleh data gaya yang keadaan tunak untuk semua geometri dalam batas yang telah ditentukan,

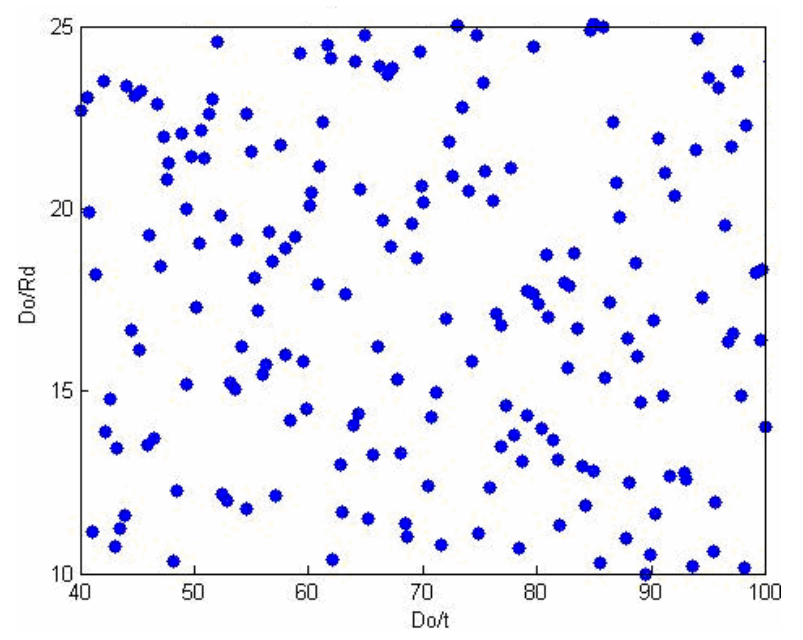

Gambar 10. Distribusi Titik Sampel Hasil LHS diputuskan untuk menggunakan interval 0,55h$0,63 h$ ( $h$ adalah panjang pipa) sebagai interval pengambilan data respon gaya keadaan tunak. Sementara data energi diambil pada saat panjang stroke 0,9 dari panjang pipa. Proses pembacaan, pengolahan hasil analisis elemen hingga Ansys/LsDyna, penyusunan dan penyimpanan hasil (file basis data) dilakukan dengan software Matlab.

\section{Penyusunan Basis Data}

Hasil akhir berupa satu file yang memuat semua pasangan parameter masukan dan parameter keluaran dari analisis elemen hingga. File ini merupakan basis data yang akan digunakan dalam proses metamodeling. Contoh basis data untuk diameter pipa $101.6 \mathrm{~mm}$ dapat dilihat pada Tabel 1 . Data $D o / t$ dan $D o / R d$ yang terdapat dalam tabel adalah sampel parameter masukan yang digenerasi menggunakan metode Latin Hypercube, sedangkan $F_{S S} /(D o . t)$ dan $E_{o} / V$ adalah parameter keluaran hasil analisis elemen hingga untuk parameter masukan tersebut. File ini merupakan basis data yang akan digunakan dalam proses metamodeling. Melalui metamodeling, basis data akan digunakan untuk mengetahui korelasi numerik antara parameter perancangan dengan parameter crashworthiness modul.

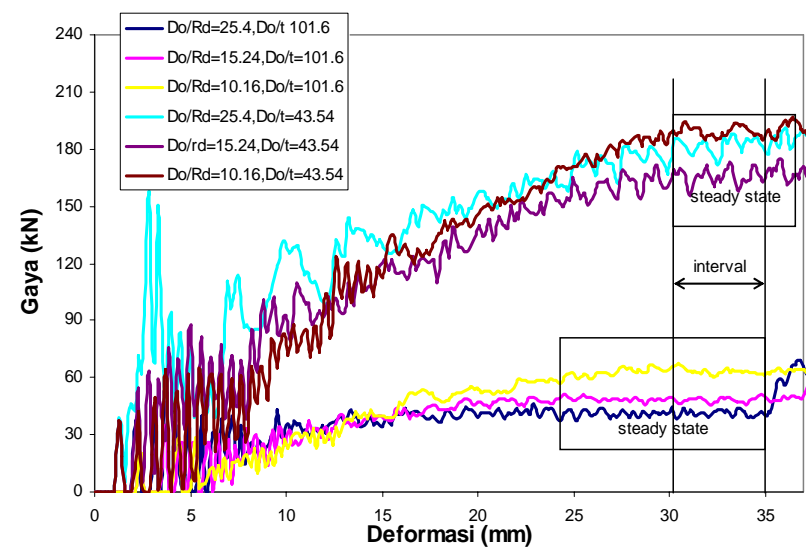

Gambar 11. Respon Gaya untuk Diameter Pipa 76,2 $\mathbf{m m}$

Tabel 1. Basis Data Untuk Diameter Pipa 101,6 mm

\begin{tabular}{ccccc}
\hline $\begin{array}{c}\text { Diameter } \\
(\mathbf{m m})\end{array}$ & Do/t & Do/Rd & $\begin{array}{l}\boldsymbol{F}_{\text {SS }}(\mathbf{D o . t}) \\
\left(\boldsymbol{k N} / \mathbf{m m}^{2}\right)\end{array}$ & $\begin{array}{l}\boldsymbol{E} \boldsymbol{d} \boldsymbol{N} \\
\left(\mathbf{k J} / \mathbf{m m}^{3}\right)\end{array}$ \\
\hline 101,6 & 43,21 & 13,43 & $1,2678 \mathrm{E}+00$ & $3,9280 \mathrm{E}-04$ \\
101,6 & 47,55 & 20,84 & $1,2127 \mathrm{E}+00$ & $4,5015 \mathrm{E}-04$ \\
101,6 & 62,76 & 12,98 & $1,0939 \mathrm{E}+00$ & $3,0632 \mathrm{E}-04$ \\
101,6 & 86,97 & 20,75 & $8,0821 \mathrm{E}-01$ & $2,4826 \mathrm{E}-04$ \\
101,6 & 47,78 & 21,28 & $1,2147 \mathrm{E}+00$ & $4,5563 \mathrm{E}-04$ \\
101,6 & 99,97 & 14,01 & $8,9321 \mathrm{E}-01$ & $2,2800 \mathrm{E}-04$ \\
101,6 & 85,88 & 15,40 & $8,9169 \mathrm{E}-01$ & $2,3753 \mathrm{E}-04$ \\
101,6 & 91,54 & 12,67 & $9,8044 \mathrm{E}-01$ & $2,4528 \mathrm{E}-04$ \\
\hline
\end{tabular}




\section{KESIMPULAN}

Dari proses penyusunan basis data ini disimpulkan bahwa parameter dimensi $D_{o} / t$ dan $D_{o} / R_{d}$, memberikan karakteristik respon gaya yang mendekati ideal pada $40 \leq D_{o} / t \leq 100$ dan $10 \leq D_{o} / R_{d} \leq 25$, sehingga ruang perancangan ditentukan dalam batas-batas tersebut. Dengan metode Latin Hypercube, diperoleh distribusi data kombinasi parameter masukan secara seragam sehingga data kombinasi parameter masukan tersebar merata dalam ruang perancangan. Hasil akhir proses penyusunan basis data disimpan dalam suatu file yang memuat data-data pasangan parameter masukan $\left(D_{o} / t\right.$ dan $\left.D_{o} / R_{d}\right)$ dan parameter keluaran $\left(E_{o} / V \operatorname{dan} F_{S S} /\left(D_{o} t\right)\right)$.

\section{DAFTAR PUSTAKA}

1. Wang Gary G., Shan S., "Review of Metamodeling Techniques in Support of Engineering Design Optimization", ASME Transaction, Journal of Mechanical Design, 2006.

2. Wang Gary G., Dong Z., Aitchison P., Adaptive Response Surface Method-A Global Optimization Scheme for Approximation-based Design Problems.
3. R Setiawan, M.H., Amir, B., dan Sugiharto, S. Fajrianto,"Karakteristik Modul Penyerap Energi Impak Mekanisme Internal inversion dan Axial Splitting”, Jurnal Teknik Mesin, Vol. 21, No. 2, hal 65-72, Institut Teknologi Bandung, Oktober 2006.

4. Reid, S.R. and J.J. Harrigan, "Transient effect in the quasi-static and dynamic internal inversion and nosing of metal tubes", Int. J. Mech.Sci.,Vol. 40, Nos. 2-3, pp. 263-280, 1998.

5. R Setiawan dan Delima Yanti Sari, Knowledgebased Design of Impact Energy Absorbing Module: Finite Element Modelling, The $5^{\text {th }}$ International Conference on Numerical Analysis in Engineering (NAE), Padang, 18-19 Mei 2007.

6. Macaulay, M., Introduction to Impact Engineering, Chapman and Hall, New York,1987.

7. Olsson J.M. Anders, Sandberg E Goran, "Latin Hypercube Sampling for Stochastic Finite Elemen Analysis", Journal of Engineering Mechanic, 2002. 